\title{
PRAGMATICS AND SEMANTICS
}

An Empiricist Theory 


$$
\text { , }
$$




\section{PRAGMATICS AND}

SEMANTICS

An Empiricist Theory

\section{CAROL A. KATES}

Cornell University Press

I T H A C A A N D L O N D O N 


\section{Copyright (C) 1980 by Cornell University}

All rights reserved. Except for brief quotations in a review, this book, or parts thereof, must not be reproduced in any form without permission in writing from the publisher. For information address Cornell University Press, 124 Roberts Place, Ithaca, New York 14850.

First published 1980 by Cornell University Press. Published in the United Kingdom by Cornell University Press Ltd., 2-4 Brook Street, London W1Y 1AA.

International Standard Book Number 0-80 14-1288-9

Library of Congress Catalog Card Number 80-16742

Librarians: Library of Congress cataloging information appears on the last page of the book. 
TO MY ESTEEMED

COLLEAGUE

JOYCE ELBRECHT 
